UDC 621.313.333.2

O. Gubarevych, PhD, Assoc. Prof., S. Goolak

State University of Infrastructure and Technology, 9 Kyrylivska Str., 9, Kyiv, Ukraine, 04071; e-mail: oleg.gbr@ukr.net, sgoolak@gmail.com

\title{
STUDY WAYS OF MODERN DIAGNOSIS OF INTER-TURN SHORT CIRCUITS IN STATOR WINDINGS OF ASYNCHRONOUS ENGINES WITH THE USE OF MODELING
}

\begin{abstract}
О.В. Губаревич, С.О. Гулак. Дослідження напрямів сучасних видів діагностики міжвиткових замикань в обмотках статора асинхронних двигунів з використанням моделювання. Підвищення надійності асинхронних електричних двигунів в процесі експлуатації відбувається за рахунок постійного вдосконалення існуючих та розробки нових діагностичних методів, що можливо на підставі результатів досліджень процесів, що виникають при різних дефектах двигунів. Найбільш трудомістким i складним залишається можливість діагностики та диференціювання міжвиткового замикання обмотки статора. Проведення досліджень процесів, що відбуваються при міжвиткових замиканнях і їх реалізації в діагностичному обладнанні, з урахуванням сучасних технологій, сприяє вирішенню завдання з розвитку та удосконаленню існуючих методів діагностики асинхронних двигунів. Метою роботи $€$ проведення досліджень ряду напрямків сучасних видів діагностики міжвиткового замикання обмотки статора 3 аналізом найбільш значимих показників для досягнення адекватної оцінки розпізнавання стану електродвигуна $\mathrm{i}$ вироблення рекомендацій подальшого вдосконалення методів діагностичного обладнання 3 використанням математичного моделювання. В роботі проведені дослідження електромеханічних процесів в асинхронному двигуні з використанням обраної імітаційної моделі для двигуна з неушкодженим статором і при наявності міжвиткових замикань різного ступеня, що становлять $10 \%$ та $20 \%$ зниження опору обмотки статора. За базову модель для проведення досліджень був прийнятий двигун AIP потужністю 11 кВт. Використовуючи модель для досліджуваного двигуна, був побудований годограф вектора Парку для режиму короткого замикання статора без дефектів і при зміні в результаті міжвиткового замикання комплексного опору до 80 \% в режимі короткого замикання і в режимі холостого ходу для проміжку часу від 0до $T=2 \pi / \omega$. Встановлено, що кожен 3 параметрів прояви міжвиткового замикання, який розглядається як визначальний в різних методах, має часткову інформативність, недостатню для прийняття рішення про стан обмотки двигуна і прогнозування часу його безаварійної роботи. Для збільшення вірогідності діагностування і диференціювання ступеня міжвиткового замикання в статорі необхідний системний підхід, побудований на аналізі чинників, що використовують електричні, магнітні, теплові та вібраційні параметри з обов'язковим впровадженням теорії прийняття рішень.
\end{abstract}

Ключові слова: асинхорнний електродвигун, міжвиткові замикання, обмотка статора, діагностика двигуна, підвищення надійності, імітаційне моделювання, вібрація, вектор Парку

O. Gubarevitch, S. Gulak. Study ways of modern diagnosis of inter-turn short circuits in stator windings of asynchronous engines with the use of modeling. Increasing the reliability of asynchronous electric motors during operation is due to the continuous improvement of existing and development of new diagnostic methods, which is possible on the basis of the results of studies of processes occurring in various engine defects. The most time-consuming and complex is the ability to diagnose and differentiate the inter-turn short circuit of the stator winding. Carrying out studies of processes occurring during inter-turn short circuits and their implementation in diagnostic equipment, taking into account modern technologies, contributes to solve the problems of developing and improving existing methods for diagnosing asynchronous motors. The aim of the work is to conduct research on modern types of diagnostics of the inter-turn short circuit of the stator winding with the analysis of the most significant indicators to achieve an adequate assessment of the recognition of the state of the electric motor and to develop recommendations for further improvement of diagnostic equipment methods. In this work, we studied electromechanical processes in an induction motor using mathematical modeling for an engine with an intact stator and in the presence of inter-turn short circuits of various degrees, comprising $10 \%$ and $20 \%$ reduction in stator winding resistance. The AIR $11 \mathrm{~kW}$ engine was adopted as the base model for research. Using the model for the engine under study, the hodograph of the Park vector was constructed for the stator short circuit mode without defects and when the complex resistance changes to $80 \%$ because of the inter-turn circuit in the short circuit mode and in the idle mode for a period from 0 to $T=2 \pi / \omega$. It was established that each of the parameters of the manifestation of the inter-turn circuit, which is considered as determining in various methods, has a partial information content, insufficient for deciding on the state of the motor winding and predicting the time of its trouble-free operation. To increase the reliability of diagnosing and differentiating the degree of inter-turn faults in the stator, a systematic approach based on the analysis of factors using electric, magnetic, thermal and vibration parameters with mandatory implementation is necessary decision theory.

Keywords: asynchronous electric motor, inter-turn short circuits, stator winding, diagnostics, reliability increase, simulation modeling, vibration, Park vector

\section{DOI: 10.15276/opu.1.60.2020.08}

(c) 2020 The Authors. This is an open access article under the CC BY license (http://creativecommons.org/licenses/by/4.0/). 


\section{Introduction}

Squirrel-cage three-phase asynchronous motors (AM) are one of the most common electric machines used in all areas of industrial, manufacturing, and transport industries in modern technology drives. The most efficient use of this type of electric motors is restrained by their high damageability, which is directly dependent on the current level and reliability of diagnostic methods. The most widespread are squirrel-cage asynchronous motors, given their high reliability.

However, $20 \ldots 25 \%$ of the total numbers of installed electric motors fail annually [1, 2]. Given the fairly wide scope of these engines and, often, the complexity of their operating conditions with a growing cost of failure, the requirements for their reliability, timely determination of the state and time of failure-free operation are also rapidly growing. Many malfunctions and emerging defects in difficult working conditions quickly progress and disable electric motors even with a short service life leading them to an emergency stop. Timely and reliable determination of a malfunction not only increases the reliability of engines, but also significantly reduces repair time and reduces unforeseen expenses. Domestic and foreign experience shows that the introduction of diagnostic tools is one of the most important and effective factors for increasing the economic efficiency of using this equipment in industry.

\section{Research objectives}

Improving the reliability of asynchronous electric motors during operation is due to the continuous improvement of existing diagnostic methods and the development of new methods, which is possible based on the results of studies of ongoing processes with various engine defects.

The most time-consuming and complex is the ability to diagnose and differentiate the inter-turn short circuit of the stator winding. The presence of inter-turn circuit leads to the fact that during operation of asynchronous motors in the damaged section of the coil the increased current flows, causing significant heating both in the closed loop and in adjacent coils. This entails a deterioration in the properties of the insulation of the wires, premature aging and destruction, leading to a new breakdown of insulation in the adjacent turns of the stator. The consequence of this process is the failure of the phase winding and the failure of the motor in emergency mode. In addition to increasing the temperature in the damaged winding, the appearance of inter-turn short circuits increases the vibration of the motor and worsens the energy and operational parameters of the machine. The continuation of studies of ongoing processes and their implementation in diagnostic equipment with inter-turn short circuits, taking into account modern technologies, helps to solve the problem of developing methods for diagnosing asynchronous motors at the stages of production, operation and repair, which continues to be relevant.

\section{Analysis of recent research and publications}

The most common reasons for the failure of squirrel-cage induction motors are damage to the stator windings, which according to existing statistics make up $70 . . .78 \%$ of all motor failures [3-5].

According to statistics, the most damaged element of induction motors is the stator winding, where inter-turn faults, according to various statistics, account for $33.6 \ldots 40 \%$ of all stator failures. And their timely identification is associated with difficult-to-diagnose indicators in terms of assessing the catastrophic state, making decisions on the possibility of further operation of the engine, as well as the impact of the changes on the engine performance $[4,5]$.

This issue requires separate studies to formulate clear requirements for the state and ability of the engine to operate within acceptable limits in the presence of this type of damage. Among the main operational requirements for diagnostics is the ability to monitor the status of asynchronous motors in the process of its operation. Detection of defects in the working electric motor at an early stage of development will prevent a sudden stoppage of production as a result of an accident, reduce the cost of repairing the electric motor and increase its service life.

Currently, there are a large number of modern methods for diagnosing the stator windings of induction motors, which are mainly based on monitoring the state of insulation. The control of the insulation state, in turn, is carried out by evaluating the parameters that are measured or calculated electrical or non-electrical quantities. The main methods for monitoring the state of insulation, traditionally, are control methods for increased voltage and partial discharges. These methods are mainly used to diagnose the stator winding in the manufacture of motors with a minimum life. These methods are not 
intended for the diagnosis of inter-turn short circuits. In addition to the existing insulation control methods, over the past $10 \ldots 15$ years, new methods have been developed that are considered more advanced and informative. These include: measurement of insulation resistance, insulation gap capacitance, dielectric loss tangent ( $\tan \delta$ ), leakage current [2, 5 - 7]. New methods include methods related to the measurement of the polarization index, dielectric absorption coefficient, dielectric discharge coefficient, and relaxation time [8-10]. However, the considered methods do not fully meet the task of reliability of diagnosing inter-turn short circuits at early stages, as well as the convenience of their implementation in diagnostic equipment, taking into account operational requirements. There are a number of promising developing methods based on the analysis of vibration parameters of electric motor elements [11, 12], scattering magnetic flux in the engine gap [13], secondary electromagnetic fields of the machine [7, 9], according to the temperature of various sections of the windings $[14,15]$, spectral analysis of acoustic vibrations of a running electric motor, etc. [1, 16].

Among the considered methods, the most widely used method of vibration diagnostics. The main disadvantages of the method are the need to use special vibroacoustic sensors, the complexity of their installation and the difficulty of interpreting the results. Vibrodiagnostics allows with sufficient reliability to identify defects in the bearing assembly, eccentricity and to a much lesser extent - defects in the stator winding [12].

In terms of informativeness, the method based on the analysis of the spectral characteristics of phase currents is not inferior to it. The presence in the current spectrum of the motor of characteristic frequencies of a certain value indicates the presence of damage to the electrical or mechanical part of the motor and the associated mechanical device [1, 3].

The disadvantage of spectral analysis of the current of asynchronous motors is the difficulty in estimating and interpreting the obtained values. Any amplitude-modulated frequency is taken into account in the spectrum twice, on both sides of the supply voltage. Double counting of the modulated frequency leads to insufficient diagnostic accuracy and the inability to increase the number of analyzed harmonics of the results, and therefore, such diagnostic devices for monitoring the state of the stator winding are not widely used [6].

Of great interest are modern studies on the application of the hodograph of the Park vector [16, 17] for the diagnosis of electric motors.

However, at the same time, inter-turn faults in the stator winding continue to be one of the most common and difficult to detect, at an early stage, faults. Carrying out research of processes with interturn faults taking into account modern technologies contributes to the development of diagnostics of asynchronous motors at the stages of production, operation and repair.

\section{The purpose and objectives of research}

The aim of the work is to conduct research on a number of areas of modern types of diagnostics of inter-turn short circuit of the stator winding with the analysis of the most significant indicators to achieve an adequate assessment of recognition of the state of the electric motor and to develop recommendations for further improvement of diagnostic equipment methods.

To achieve this goal, the following tasks were solved:

- analysis of processes during inter-turn circuit in the stator winding of an induction motor;

- research and analysis of parameters used in the diagnosis of inter-turn circuit of asynchronous motors, using simulation;

- analysis of modern methods for diagnosing inter-turn circuit;

- determination of the direction for the development of diagnostic methods of inter-turn circuit of the stator winding.

\section{Statement of the main material}

The complexity of diagnosing the inter-turn short circuit of the stator winding lies in the complex nature of the manifestations of inter-turn short circuits in a running engine, which are not individual in nature and repeat the manifestations of many other defects of the electric motor.

When an inter-turn circuit is formed in one of the stator phases, an asymmetric rotating magnetic field is created. The asymmetry is caused not only by a decrease in the active and inductive resistance 
of one of the damaged phase windings, but also by a significant change in the mutual inductance between the windings. The asymmetries caused by the defects that have arisen change the nature of the external magnetic field, causing a spectrum of spatial harmonics of induction and create the appearance of vibration due to pulsations of the moment. With inter-turn short circuit, the phase current ratio also changes, which leads to the appearance of a local overheating of the winding. In addition, a current is generated in the resulting squirrel cage in the damaged stator winding, which induces an electrodynamic force with an inductance proportional to the number of closed turns, with a direction in the opposite direction than that created by the main coil. The squirrel cage current also increases the heating of the damaged part of the winding.

The difficulty in diagnosing the inter-turn circuit by electrical resistance lies in the fact that when short circuit of several turns, with their total number of several hundred, it is almost impossible to fix the change in active resistance, since it varies within a few percent of the total value.

Thus, the most significant manifestations of inter-turn circuit of the stator winding for analyzing the process and diagnostic method are increased current in phase with a damaged winding, increased heating of part of the damaged winding, increased overall vibration of the machine, distortion of the picture of the field of the real state of the motor, for which the spectral method is used analysis of modules of vectors of the Park of current and voltage. In addition, when conducting diagnostics, it is necessary to take into account external factors, such as the quality of the supply voltage, which is not ideally sinusoidal and manifests itself as an inter-turn short circuit, as well as interference and vibration from extraneous devices and mechanisms.

It is advisable to analyze the changes in the motor parameters caused by the inter-turn circuit in the stator winding using modern methods of simulation mathematical modeling. Models for studying the parameters of squirrel-cage induction motors are considered in a number of works [18-20]. For research, a mathematical model was adopted with the established adequacy to real processes in an induction motor, given in [18] with its implementation in the OrCAD software environment [21]. In conducting the research, the methodology cited also in [22] was used.

For the basic model for research, an asynchronous squirrel-cage rotor motor of the AIR series with a power of $11.0 \mathrm{~kW}$ was adopted, the passport data of which are given in Table 1.

Table 1

Passport data of squirrel-cage asynchronous motor

\begin{tabular}{l|c|c|c}
\hline \multicolumn{1}{c|}{ Parameter } & Designation & $\begin{array}{c}\text { Unit of } \\
\text { measurement }\end{array}$ & Value \\
\hline Shaft Power Rating & $P_{n}$ & $\mathrm{~kW}$ & 11.0 \\
\hline Rated phase voltage & $U_{n}$ & $\mathrm{~V}$ & 220 \\
\hline Supply voltage frequency & $f_{n}$ & $\mathrm{~Hz}$ & 50 \\
\hline Stator field rotation frequency & $n_{n \text {.idle }}$ & $\mathrm{rpm}$ & 1500 \\
\hline Load idle & $M_{\text {idle }}$ & $\mathrm{N} \cdot \mathrm{m}$ & 0.38 \\
\hline Idle current & $I_{\text {S.idle }}$ & $\mathrm{A}$ & 9.44 \\
\hline Amplitude of idling current & $I_{\text {S.iAdle }}$ & $\mathrm{A}$ & 13.35 \\
\hline Stator winding resistance & $r_{1}$ & $\Omega$ & 0.5 \\
\hline Active resistance of the rotor winding reduced to the stator winding & $r_{2}^{\prime}$ & $\Omega$ & 0.36 \\
\hline Stator winding reactance & $x_{1}$ & $\Omega$ & 0.56 \\
\hline Rotor winding reactance reduced to stator winding & $x_{2}^{\prime}$ & $\Omega$ & 0.938 \\
\hline Rated rotor speed & $n_{n}$ & $\mathrm{rpm}$ & 1450 \\
\hline Motor rated torque & $M_{n}$ & $\mathrm{~N} \cdot \mathrm{m}$ & 72.671 \\
\hline
\end{tabular}


For an intact stator, first in idle mode and then in nominal mode using simulation, the following basic values and parameters of the motor are determined: shaft rotation speed, average, maximum and minimum electromagnetic moments and torque ripple frequency. In the course of the research, the values of the current stator phase currents, the lag angles of the stator phase currents from the voltages, the current rotor phase currents, the lag angles of the rotor phase currents from the stator voltages for the engine under study were also determined. At the next stage, the values of similar parameters were determined with a decrease in the phase resistance by $10 \%$ and by $20 \%$, which imitates the inter-turn circuit of the various sections of damage to the stator winding. The simulation results are shown in Table 2. The same parameters in the research process were also determined with a decrease in the complex phase resistance by $10 \%$ and $20 \%$ as well. The simulation results when reducing the complex resistance of the stator phase are shown in Table 3.

Table 2

The results of modeling asynchronous motor operation with an intact stator and in the presence of inter-turn circuit (when changing the active resistance)

\begin{tabular}{|c|c|c|c|c|c|c|}
\hline \multirow{3}{*}{ Parametr } & \multicolumn{3}{|c|}{ Idling } & \multicolumn{3}{|c|}{ Rated mode } \\
\hline & \multirow{2}{*}{$\begin{array}{l}\text { Intact } \\
\text { Stator }\end{array}$} & \multicolumn{2}{|c|}{ Active resistance } & \multirow{2}{*}{$\begin{array}{l}\text { Intact } \\
\text { Stator }\end{array}$} & \multicolumn{2}{|c|}{ Active resistance } \\
\hline & & $90 \%$ & $80 \%$ & & $90 \%$ & $80 \%$ \\
\hline Rotation frequency, $n$, rpm & 1500 & 1500 & 1500 & 1451.2 & 1451.2 & 1451.2 \\
\hline Average electromagnetic moment $M_{\text {mid }}, \mathrm{N} \cdot \mathrm{m}$ & 0.38 & 0.38 & 0.38 & 72.671 & 72.671 & 72.671 \\
\hline Maximum electromagnetic moment $M_{\max }, \mathrm{N} \cdot \mathrm{m}$ & 0.38 & 0.793 & 1.209 & 72.671 & 73.524 & 74.386 \\
\hline Minimum electromagnetic moment $M_{\min }, \mathrm{N} \cdot \mathrm{m}$ & 0.38 & -0.0329 & -0.449 & 72.671 & 71.818 & 70.957 \\
\hline Pulsation frequency of the moment, $f_{p u l s}, \mathrm{~Hz}$ & 100 & 100 & 100 & 100 & 100 & 100 \\
\hline Effective stator $A$ phase current, $I_{1 A}, \mathrm{~A}$ & 9.399 & 9.442 & 9.485 & 21.612 & 21.685 & 21.757 \\
\hline Effective stator $B$ phase current, $I_{1 B}, \mathrm{~A}$ & 9.399 & 9.19 & 9.198 & 21.612 & 21.363 & 21.114 \\
\hline Effective stator $C$ phase current, $I_{1 C}, \mathrm{~A}$ & 9.399 & 9.349 & 9.52 & 21.612 & 21.723 & 21.84 \\
\hline $\begin{array}{l}\text { The angle of current lag from voltage in } A \text { phase, } \\
\varphi_{1 A} \text {, grad }\end{array}$ & 88.814 & 89.357 & 90 & 31.5 & 31.5 & 31.5 \\
\hline $\begin{array}{l}\text { The angle of current lag from voltage in } B \text { phase, } \\
\varphi_{1 B} \text {, grad }\end{array}$ & 88.814 & 88.071 & 88.071 & 31.5 & 31.5 & 30.857 \\
\hline $\begin{array}{l}\text { The angle of current lag from voltage in } C \text { phase, } \\
\varphi_{1 C} \text {, grad }\end{array}$ & 88.814 & 88.393 & 87.429 & 31.5 & 30.857 & 30.214 \\
\hline Effective rotor $A$ phase current, $I_{2 A}, \mathrm{~A}$ & 0.093 & 0.045 & 0.120 & 18.713 & 18.686 & 18.658 \\
\hline Effective rotor $B$ phase current, $I_{2 B}, \mathrm{~A}$ & 0.093 & 0.138 & 0.221 & 18.713 & 18.493 & 18.276 \\
\hline Effective rotor $C$ phase current, $I_{2 C}, \mathrm{~A}$ & 0.093 & 0.182 & 0.277 & 18.713 & 18.873 & 19.036 \\
\hline $\begin{array}{l}\text { The angle of lag of the rotor current from the } \\
\text { voltage in the stator } A \text { phase, } \varphi_{2 A} \text {, deg }\end{array}$ & 178.737 & 264.12 & 307.579 & 186.316 & 187.579 & 187.58 \\
\hline $\begin{array}{l}\text { The angle of lag of the rotor current from the } \\
\text { voltage in the stator } B \text { phase, } \varphi_{2 B} \text {, deg }\end{array}$ & 178.737 & 132.632 & 114.947 & 186.316 & 186.947 & 185.68 \\
\hline $\begin{array}{l}\text { The angle of lag of the rotor current from the } \\
\text { voltage in the stator } C \text { phase, } \varphi_{2 C} \text {, deg }\end{array}$ & 178.737 & 197.053 & 202.737 & 186.316 & 186.316 & 186.32 \\
\hline $\begin{array}{l}\text { Pulsation coefficient of electromagnetic moment, } \\
k_{\text {pulsM }}, \%\end{array}$ & 0 & 108.6 & 218.2 & 0 & 1.2 & 2.4 \\
\hline $\begin{array}{l}\text { Stator phase current unbalance coefficient, } \\
k_{\text {puls }_{1}}, \%\end{array}$ & 0 & 1.685 & 3.423 & 0 & 1.665 & 3.363 \\
\hline
\end{tabular}


The results of modeling the operation of an asynchronous motor with an intact stator and in the presence of inter-turn circuit (when changing the complex resistance)

\begin{tabular}{|c|c|c|c|c|c|c|}
\hline \multirow{3}{*}{ Parametr } & \multicolumn{3}{|c|}{ Idling } & \multicolumn{3}{|c|}{ Rated mode } \\
\hline & \multirow{2}{*}{$\begin{array}{l}\text { Intact } \\
\text { Stator }\end{array}$} & \multicolumn{2}{|c|}{ Complex resistance } & \multirow{2}{*}{$\begin{array}{l}\text { Intact } \\
\text { Stator }\end{array}$} & \multicolumn{2}{|c|}{ Complex resistance } \\
\hline & & $90 \%$ & $80 \%$ & & $90 \%$ & $80 \%$ \\
\hline Rotation frequency, $n, \mathrm{rpm}$ & 1500 & 1500 & 1500 & 1451.2 & 1451.2 & 1451.2 \\
\hline Average electromagnetic moment $M_{\text {mid }}, \mathrm{N} \cdot \mathrm{m}$ & 0.38 & 0.38 & 0.38 & 72.671 & 72.671 & 72.671 \\
\hline Maximum electromagnetic moment, $M_{\max }, \mathrm{N} \cdot \mathrm{m}$ & 0.38 & 1.008 & 1.658 & 72.671 & 73.967 & 75.307 \\
\hline Minimum electromagnetic moment $M_{\min }, \mathrm{N} \cdot \mathrm{m}$ & 0.38 & -0.248 & -0.899 & 72.671 & 71.376 & 70.036 \\
\hline Pulsation frequency of the moment, $f_{\text {puls }}, \mathrm{Hz}$ & 100 & 100 & 100 & 100 & 100 & 100 \\
\hline Effective stator $A$ phase current, $I_{1 A}, \mathrm{~A}$ & 9.399 & 9.554 & 9.714 & 21.612 & 21.905 & 22.207 \\
\hline Effective stator $B$ phase current, $I_{1 B}, \mathrm{~A}$ & 9.399 & 9.296 & 9.19 & 21.612 & 21.323 & 21.027 \\
\hline Effective stator $C$ phase current, $I_{1 C}, \mathrm{~A}$ & 9.399 & 9.373 & 9.349 & 21.612 & 21.5 & 21.324 \\
\hline $\begin{array}{l}\text { The angle of current lag from voltage in phase } A, \\
\varphi_{1 A} \text {, deg }\end{array}$ & 88.814 & 88.071 & 89.036 & 31.5 & 31.5 & 32.143 \\
\hline $\begin{array}{l}\text { The angle of current lag from voltage in phase } B \text {, } \\
\varphi_{1 B} \text {, deg }\end{array}$ & 88.814 & 88.071 & 90 & 31.5 & 31.5 & 32.786 \\
\hline $\begin{array}{l}\text { The angle of current lag from voltage in phase } C \text {, } \\
\varphi_{1 C} \text {, deg }\end{array}$ & 88.814 & 87.429 & 86.786 & 31.5 & 30.857 & 28.929 \\
\hline Effective rotor $A$ phase current, $I_{2 A}, \mathrm{~A}$ & 0.093 & 0.153 & 0.291 & 18.713 & 18.914 & 19.098 \\
\hline Effective rotor $B$ phase current, $I_{2 B}, \mathrm{~A}$ & 0.093 & 0.104 & 0.243 & 18.713 & 18.349 & 17.989 \\
\hline Effective rotor $C$ phase current, $I_{2 C}, \mathrm{~A}$ & 0.093 & 0.238 & 0.39 & 18.713 & 18.729 & 18.771 \\
\hline $\begin{array}{l}\text { The angle of lag of the rotor current from the } \\
\text { voltage in the stator } A \text { phase, } \varphi_{2 A} \text {, deg }\end{array}$ & 178.737 & 247.579 & 265.263 & 186.316 & 186.947 & 187.9 \\
\hline $\begin{array}{l}\text { The angle of lag of the rotor current from the } \\
\text { voltage in the stator } B \text { phase, } \varphi_{2 B} \text {, deg }\end{array}$ & 178.737 & 78.947 & 60.0 & 186.316 & 186.947 & 186.95 \\
\hline $\begin{array}{l}\text { The angle of lag of the rotor current from the } \\
\text { voltage in the stator } C \text { phase, } \varphi_{2 C} \text {, deg }\end{array}$ & 178.737 & 168.0 & 166.737 & 186.316 & 186.684 & 185.05 \\
\hline $\begin{array}{l}\text { Pulsation coefficient of electromagnetic moment, } \\
k_{\text {pulsM }}, \%\end{array}$ & 0 & 165.2 & 336.5 & 0 & 1.8 & 3.6 \\
\hline $\begin{array}{l}\text { Stator phase current unbalance coefficient, } \\
k_{\text {puls }_{1}}, \%\end{array}$ & 0 & 2.746 & 5.575 & 0 & 2.693 & 5.457 \\
\hline
\end{tabular}

Based on the simulation results shown in Tables 2 and 3, graphs of the change in the ripple coefficient of the electromagnetic moment and the unbalance coefficient of the stator phase currents are plotted depending on the changes in the active (Fig. 1) and complex (Fig. 2) $A$ stator phase resistance for idling and nominal mode.

As can be seen from Fig. 1 and Fig. 2, the most significant changes occur with the pulsation of the electromagnetic moment when the active and complex resistance of one of the phases changes at idle. Therefore, it is advisable to diagnose the inter-turn short circuit using the methods of vibration diagnostics in idle mode. However, it should be borne in mind that mechanical malfunctions of the electric motor and the type of mechanical load and the corresponding harmonics in the current spectrum also cause vibration of the machine, which complicates a reliable and unambiguous interpretation of the type of defect based on the spectral analysis of the vibrational frequency. 

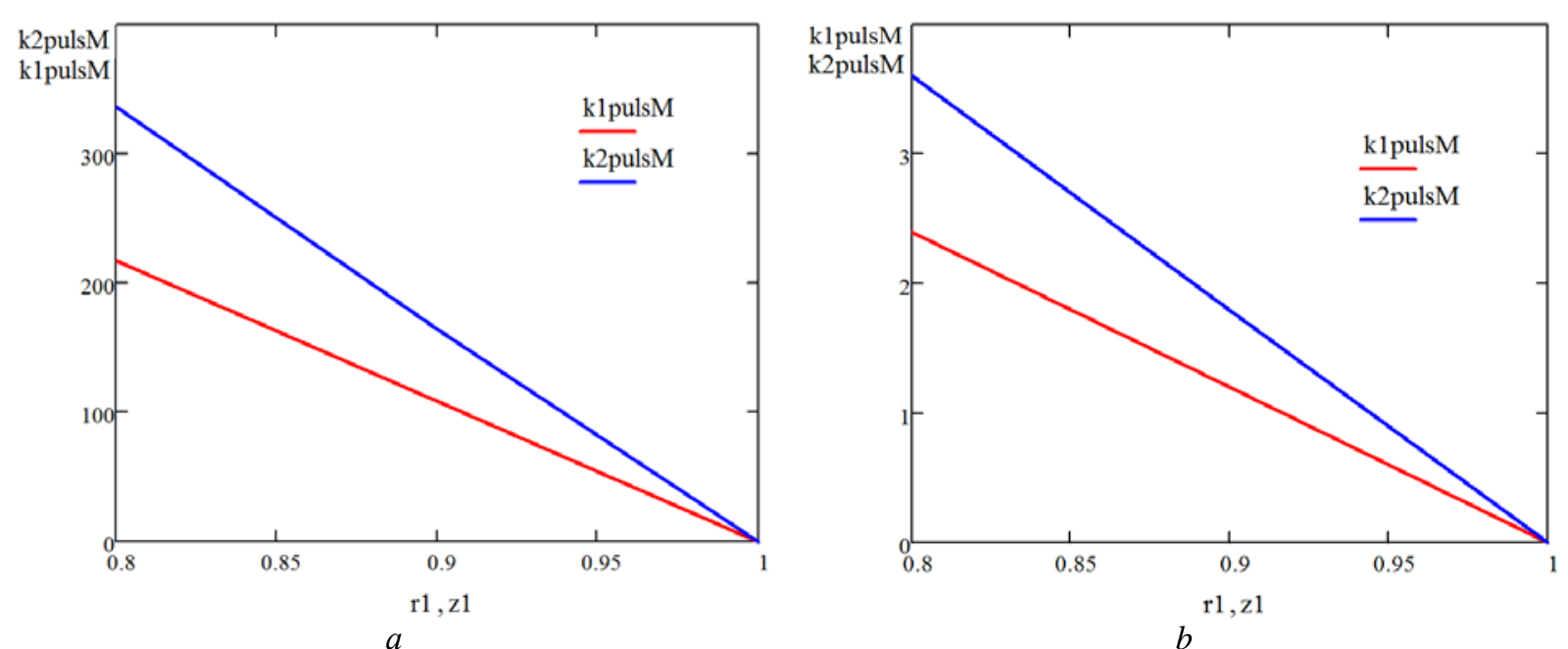

Fig. 1. The dependence of the ripple factor of electromagneticmoment from change in $A$ stator phase resistance: $k 1_{\text {puls }}, \%$ - active resistance $r 1, \%$ in idle mode, $k 2_{\text {puls }}, \%$ - integrated resistance $z 1, \%$ in nominal mode (a); $k 1_{\text {pulsM }}, \%$ - active resistance $r 1, \%$ in nominal mode, $k 2_{\text {pulsM }}, \%$ - integrated resistance $z 1, \%$ in nominal mode (b)
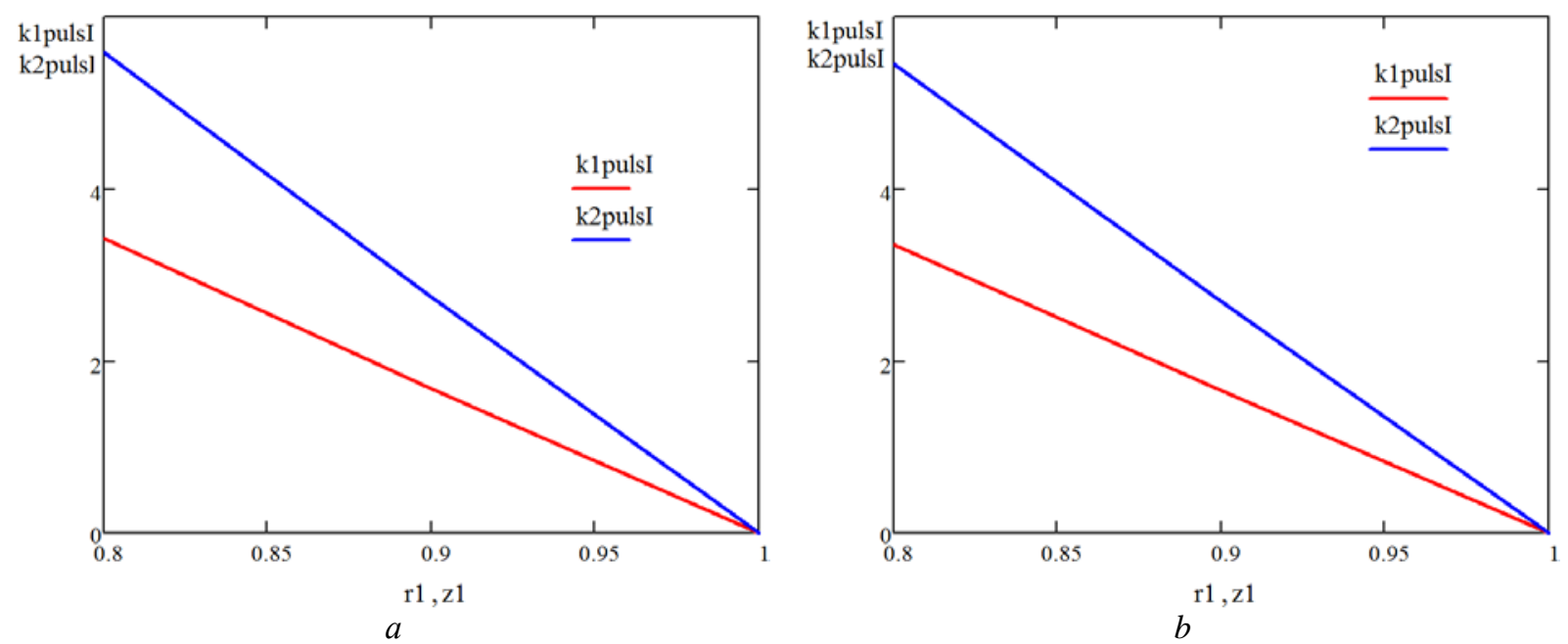

Fig. 2. The dependence of the unbalance coefficient of the stator phase currents on the change in the resistance of the stator phase: $k 1_{\text {puls } I_{1}}, \%$ )- active resistance $r 1, \%$ in idle mode, $k 2_{\text {puls } I_{1}}, \%$ - integrated resistance $\mathrm{z} 1, \%$ in idle mode (a); $k 1_{\text {puls } I_{1}}, \%$ - active resistance $r 1, \%$ in nominal mode, $k 2_{\text {puls } I_{1}}, \%$ - integrated resistance $\mathrm{z} 1, \%$ in nominal mode (b)

The unbalance coefficient of the stator phase currents (Fig. 2) changes slightly, both the active and complex resistance of one of the motor phases. From this, it follows that when using the unbalance coefficient of the stator phase currents, as a criterion for determining the inter-turn short circuit of the motor, it will be difficult. Direct measurement of the consumed currents in phases requires stopping and turning off the equipment, which does not correspond to modern diagnostic requirements and operating conditions. In addition, the stator currents also carry information about the breakage of the rotor rods, misalignment, static or dynamic eccentricity.

The following is a study of the hodograph of the Park vector with a decrease in the complex resistance of the stator winding by $20 \%$ caused by inter-turn closure. The Park vector is a mathematical tool used to simplify the analysis, which allows describing three phase variables in two orthogonal 
planes. It is used in industry to detect such malfunctions of three-phase asynchronous motors, such as asymmetry of the supply voltage, eccentricity of the air gap, inter-turn defects in the stator winding, misalignment of the mechanical connections, an open in the phase rotor winding, and defects in rods and rings of the squirrel-cage rotor. In contrast to the traditional spectral analysis of current signals during the formation of the spectra of the Park vector module, any characteristic frequency modulated by amplitude modulation is taken into account in the spectrum of the Park vector only once. The harmonics in the spectrum corresponding to different types of faults differ from each other. Thus, the identification of characteristic harmonics in the spectrum reliably and unambiguously indicates the presence of electrical and mechanical malfunctions in the electric motor and in the device it drives [19], which allows diagnosing inter-turn short circuits as well.

To conduct studies using the hodograph method of the Park vector, it is necessary to introduce into the used model of the induction motor a block for calculating the stator current components along the axes $X, Y\left(I_{1 X}, I_{1 Y}\right)$, and the amplitude of the stator current $I_{1 Z 0}$ representing the current.

For this, the stator current was projected on $X$ and $Y$ axis. The cosine components of the stator current were projected onto the $X$ axis, and sinusoidal components were projected onto the $Y$ axis. Then, after the transition from the current values of the current to the amplitudes, the projection of the stator current on the axis will have the form [19]:

$$
\begin{gathered}
I_{1 X}=\frac{2}{3} \cdot\left(I_{1 A} \cdot \cos \left(\omega \cdot t+\varphi_{1 A}\right) \cdot \cos 0^{\circ}+I_{1 B} \cdot \cos \left(\omega \cdot t+\varphi_{1 B}\right) \cdot \cos \left(-120^{\circ}\right)+\right. \\
\left.+I_{1 B} \cdot \cos \left(\omega \cdot t+\varphi_{1 C}\right) \cdot \cos 120^{\circ}\right)
\end{gathered}
$$

and the projection on the $Y$ axis:

$$
\begin{gathered}
I_{1 Y}=\frac{2}{3} \cdot\left(I_{1 A} \cdot \sin \left(\omega \cdot t+\varphi_{1 A}\right) \cdot \sin 0^{\circ}+I_{1 B} \cdot \sin \left(\omega \cdot t+\varphi_{1 B}\right) \cdot \sin \left(-120^{\circ}\right)+\right. \\
\left.+I_{1 B} \cdot \sin \left(\omega \cdot t+\varphi_{1 C}\right) \cdot \sin 120^{\circ}\right)
\end{gathered}
$$

where $\omega$ - angular frequency; $t$-time.

The amplitude of the stator current imaging vector $[7,8]$ :

$$
I_{1 Z 0}=\sqrt{\left(I_{1 X}\right)^{2}+\left(I_{1 Y}\right)^{2}} \text {. }
$$

In Fig. 3 shows a block made in the OrCAD software environment, which implements expressions $(1-3)$.

Using the model [21] and the calculation unit (Fig. 3) for the time interval from 0 to $T=2 \pi / \omega$, the hodograph of the Park vector was constructed for the stator short circuit mode without defects (Fig. $4 \mathrm{a}$ ), when the complex resistance changes to $80 \%$ as a result of the inter-turn circuit short circuit mode (Fig. 4, b) and in idle mode (Fig. 4, c).

As the analysis of the hodograph of the Park vector shown in Fig. $4 a$, in the absence of inter-turn short circuit, the hodograph describes the correct circle in the scale shown in the figure. Reducing the complex resistance to $80 \%$ of the nominal, simulating damage in the stator winding, leads to an elliptical shape of the hodograph Fig. $4 b$ while maintaining the image scale. The degree of ellipticity will be proportional to the degree of damage, and the orientation of the ellipse depends on which phase winding there is inter-turn damage. From Fig. $4 a$ and $b$, it follows that when the complex resistance changes because of the appearance of an inter-turn short circuit, the main axes of the ellipse and the hodograph scale differ slightly in size from each other. Comparison and analysis of the hodograph in Fig. $4 b$ and $4 c$ shows that the sensitivity to the same defect in different operating modes is different, as evidenced by the reduced scale (grid) of Fig. 4, c. The decrease in the hodograph of the Park vector in size makes it difficult to identify defects such as inter-turn short circuit. However, at the same time, the method of diagnosing asynchronous motors based on spectral analysis of the current and voltage park vectors in comparison with other diagnostic methods has a number of the following advantages:

- a wide range of diagnosed injuries and increased diagnostic accuracy;

- the ability to diagnose not only the main types of defects in the electric motor, but also the associated mechanical device;

- reducing the complexity of the diagnostic procedure; 
- the possibility of remote diagnostics (at a distance from the electric motor - in the power supply and / or control panel);

- simplification of the diagnostic procedure: it is not necessary to turn off the electric motor and / or to remove the load;

- the ability to fully automate the diagnostic process $[16,17]$.

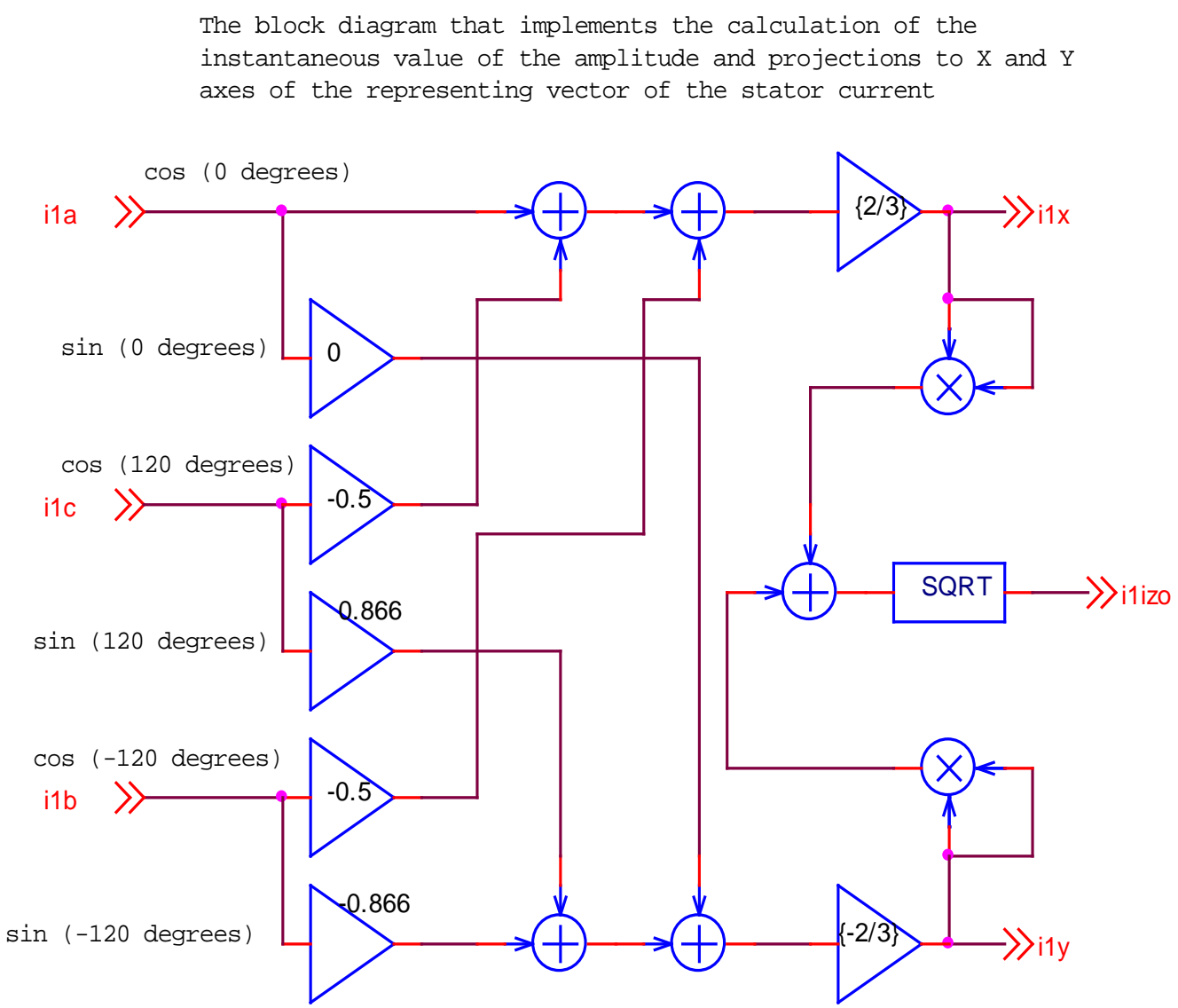

Fig. 3. The unit for calculating the components of the stator current along the $X, Y\left(I_{1 X}, I_{1 Y}\right)$ axes, and the amplitude of the depicting stator current $I_{1 z 0}$

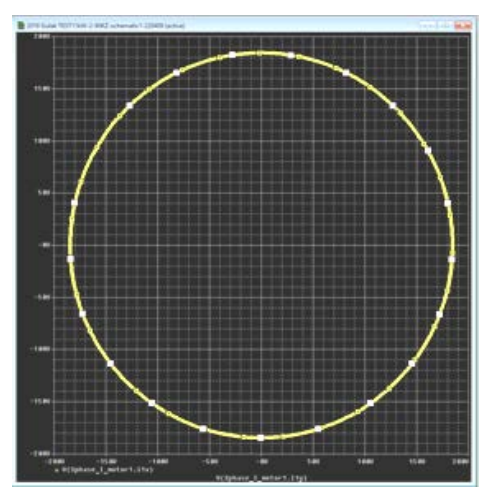

$a$

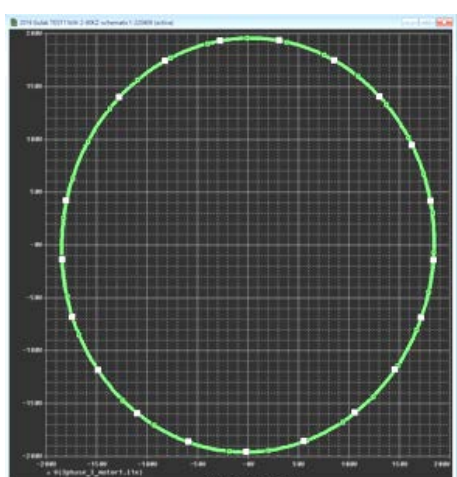

$b$

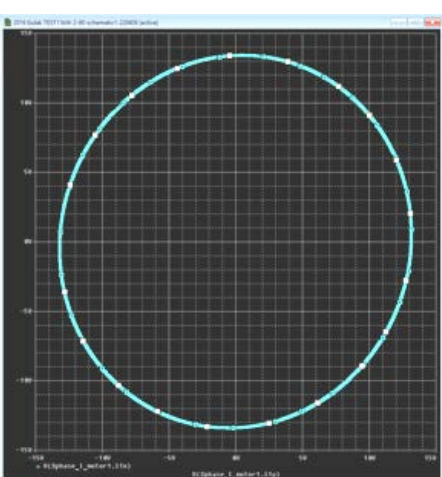

$C$

Fig. 4. Hodograph of the Park vector: stator winding without defects in short circuit mode (a); with a complex resistance of $80 \%$ in the short circuit mode (b); with a complex resistance of $80 \%$ in idle mode (c) 
When applying the method of spectral analysis of stator current and spectral analysis of modules of vectors of the Park of current and voltage, one should take into account the influence on the electric parameters of the drive of the supply network parameters, the nature of the load, the influence of external electromagnetic fields, transient processes in the drive, which makes the use of this method not fully adequate requirements of practice. In addition, these methods make it possible to detect a stator winding defect already at a late stage of development.

The next method for determining of the inter-turn circuit can be a method based on comparing the temperature of the stator winding without damage and the temperature of the stator winding in the presence of inter-turn circuit at the same ambient temperature.

The excess of the temperature of the stator winding over the ambient temperature can be taken into account in the simulation model by the following relation [23]:

$$
\theta_{m}=\left(\frac{\Delta P_{\text {cop }} \cdot\left(1+\frac{\alpha \cdot t_{1}}{\lambda_{\text {ins }} \cdot p}\right)+\Delta P_{\text {st }} \cdot\left(1-\frac{\alpha \cdot t_{1}}{\lambda_{\text {ins }} \cdot p} \cdot \frac{L_{\text {front }}}{l_{a}}\right)}{\alpha \cdot\left(S_{\text {chan }}+S_{\text {front }}\right) \cdot 10000}\right) \cdot k_{1}+\theta_{\text {air }},
$$

where $\alpha=0.0165$ - heat transfer coefficient. $\frac{\mathrm{W}}{\mathrm{cm}^{2} \cdot{ }^{\circ} \mathrm{C}}$;

$\lambda_{\text {ins }}=0.118$ - thermal conductivity of insulation, $\frac{\mathrm{W}}{\mathrm{cm}^{2} \cdot{ }^{\circ} \mathrm{C}}$;

$p$ - calculated reduced slot parameter $[4,5]: p=1,33 \cdot b_{g r}+2 \cdot h_{z 1}$;

$k_{1}=0.91$ - the coefficient of accounting for the implementation of the frontal parts open;

$\theta_{\text {air }}=20,{ }^{\circ} \mathrm{C}$ - air temperature, deg.

Active losses in stator winding copper:

$$
\Delta P_{\text {cop }}=t_{r} \cdot k_{f 1} \cdot\left(I_{1 A}^{2} \cdot r_{1 A}+I_{1 B}^{2} \cdot r_{1 B}+I_{1 C}^{2} \cdot r_{1 C}\right),
$$

where $I_{1 A}, I_{1 B}, I_{1 C}$ - the amplitude of the effective values of the stator phase currents, A;

$r_{1 A}, r_{1 B}, r_{1 C}$ - active stator phase resistances, Ohm;

$t_{r}$ - temperature coefficient of increase in copper resistance, deg.;

$k_{f 1}=1,038$ - stator current first harmonic coefficient.

For asymmetric modes that arise when modeling the inter-turn circuit, in the expression (5), instead of the squares of the effective values of the stator currents, substitute the values of the sum of the squares of the currents of the forward, reverse and zero sequence, which are calculated by the expressions $(6-9)$ [24].

Direct sequence currents are defined by expressions:

$$
\dot{I}_{1 A d i r}=\frac{1}{3} \cdot\left(\dot{I}_{1 A}+a \cdot \dot{I}_{1 B}+a^{2} \cdot \dot{I}_{1 C}\right), \quad \dot{I}_{1 B d i r}=a^{2} \cdot \dot{I}_{1 A d i r}, \quad \dot{I}_{1 C d i r}=a \cdot \dot{I}_{1 A d i r},
$$

where $a=e^{j 120^{\circ}}$,

$$
\dot{I}_{1 \mathrm{~A}}=I_{1 \mathrm{~A}} \cdot e^{j \varphi_{1 A}}, \quad \dot{I}_{1 \mathrm{~B}}=I_{1 \mathrm{~A}} \cdot e^{j\left(-120+\varphi_{1 B}\right)}, \quad \dot{I}_{1 C}=I_{1 \mathrm{~A}} \cdot e^{j\left(120+\varphi_{1 C}\right)},
$$

where $\varphi_{1 A}, \varphi_{1 B}, \varphi_{1 C}$ - the lag angles of the current currents of the stator phases from the stresses.

The reverse sequence of currents is determined by the expressions:

$$
\dot{I}_{1 \mathrm{Arev}}=\frac{1}{3} \cdot\left(\dot{I}_{1 \mathrm{~A}}+a^{2} \cdot \dot{I}_{1 B}+a \cdot \dot{I}_{1 C}\right), \quad \dot{I}_{1 \mathrm{Brev}}=a \cdot \dot{I}_{1 \mathrm{Arev}}, \quad \dot{I}_{1 \mathrm{Crev}}=a^{2} \cdot \dot{I}_{1 \mathrm{Arev}} .
$$

The zero sequence of currents is determined by the expression:

$$
\dot{I}_{10}=\frac{1}{3} \cdot\left(\dot{I}_{1 A}+\dot{I}_{1 B}+\dot{I}_{1 C}\right),
$$


The temperature coefficient of increase in copper resistance is determined by the expression [23]:

$$
t_{r}=1+\beta \cdot\left(\theta-20^{\circ} \mathrm{C}\right)
$$

where $\theta$ - predicted stator winding temperature;

\section{$\beta=0.004,{ }^{\circ} \mathrm{C}^{-1}$ - temperature coefficient of resistance of copper.}

Using the above ratios will allow obtaining the temperature of the stator winding for various operating modes, taking into account the presence of defects in it. Condition monitoring and diagnostics of inter-turn circuits by thermal state is possible with the installation of special sensors, but it is impossible to obtain a reliable result on the form of a winding defect and prediction of a trouble-free operation period.

Based on the analysis, the most significant methods for diagnosing inter-turn circuits of asynchronous motors include methods based on:

- analysis of the electrical parameters of the machine;

- vibration analysis;

- measurement and analysis of an external magnetic field;

- measurement and analysis of stator temperature.

In addition, studies of modern areas of state monitoring and analysis of methods for diagnosing inter-turn circuits of the stator showed that the issue of determining inter-turn circuit in the stator phase continues to be relevant for a number of the following reasons. Among them, insufficient study of individual processes and the absence of dominant parameters for the manifestation of damage to the winding, as well as uncertainty in the values of specific diagnostic parameters characterizing the change in the functioning processes when the corresponding damage to the winding occurs. They also include the lack of forecasting methods for the obtained values of a parameter of the residual resource of the winding. The available criteria take into account only the maximum or permissible state of the parameters, which does not allow evaluating defects at an early stage of their development.

Studies of modern directions of diagnostics of the stator winding, based on the control of the main manifestations of inter-turn circuits using mathematical modeling methods, can be used to further improve the diagnostic equipment.

\section{Research results}

The study of electromechanical processes in an asynchronous motor using mathematical modeling with an intact stator and in the presence of inter-turn circuits of various degrees, constituting a $10 \%$ and $20 \%$ reduction in the resistance of the stator winding. Based on the analysis of the obtained data, it is established that the average electromagnetic torque of the engine in the presence of damage in the nominal mode and in the idle mode remains constant. At the same time, the maximum electromagnetic torque for the undamaged stator in idle mode and in nominal mode increases. In the nominal mode for an intact stator, the maximum electromagnetic moment is $72.671 \mathrm{Nm}$ and, with an increase in the degree of damage, has such values - for $10 \%-73.524 \mathrm{Nm}$, for $20 \%-74.386 \mathrm{Nm}$. In this case, the current in the damaged phase of the stator increases in both modes of the motor. However, in the nominal mode, the current increase is more pronounced - from $21.612 \mathrm{~A}$ to $22.207 \mathrm{~A}$, while the effective current of the rotor phases is practically unchanged. The ripple coefficient of the electromagnetic moment of the investigated engine in idle mode increases from 0 (for an intact stator) to $336.5 \%$ (in the presence of damage of varying degrees), and in the nominal mode from 0 to $3.6 \%$. The unbalance coefficient $k_{\text {puls }}, \%$ of the stator phase currents varies from 0 to $5.5 \%$ regardless of the operating mode of the motor. Studies were conducted to change the active resistance and complex stator winding separately.

In addition, using the model for the time interval from 0 to $T=2 \pi / \omega$, for the engine under study, the hodograph of the Park vector was constructed for the stator short circuit mode without defects and when the complex resistance changes up to $80 \%$ as a result of inter-turn short circuit both in the shortcircuit mode and in the short-circuit mode idle move. The analysis of the geometric shape of the hodograph of the Park vector allows us to analyze the stator currents consumed by the motor and establish image distortion in the presence of obvious damage to the winding. Differentiation of inter-turn circuit by this method is difficult due to the lack of clear levels for assessing the boundaries of distortions, the established parametric indicator of the technical condition and recommendations for interpreting the data obtained. 
According to the obtained results of simulation of the inter-turn circuit, the current in the damaged phase of the stator winding increases, which causes additional heating of the damaged part of the winding. In addition, the short-circuited turn of the winding formed because of an inter-turn short circuit, given its insignificant resistance, also creates additional heating. Therefore, one of the criteria for detecting an inter-turn circuit can be to control the thermal balance of the engine. The assessment of the thermal regime can be performed by determining the excess temperature of the stator winding over the ambient temperature and can be taken into account in the simulation model used by the ratio given in the work in further studies.

\section{Conclusions on the work}

Research and analysis of modern methods and directions of diagnosis of inter-turn circuit showed that the available diagnostic approaches for using a number of basic parameters for the manifestation of defects do not allow to clearly differentiating the type and degree of damage. In order to improve the accuracy and reliability of the diagnostic results, it is necessary to improve existing and develop new methods and tools for diagnosing asynchronous motors during operation, which have more universal approach to identifying the type and degree of damage to the winding.

When creating new universal methods, it is necessary to take into account that the following parameters are appropriate for the construction of diagnostic methods: current consumption in the stator phases at nominal mode, vibrations that are most manifested in idle mode, violation of the heat balance of individual parts of the stator, which can be estimated by exceeding stator winding temperatures above ambient temperature.

In addition, it was found that each of the parameters of the inter-turn circuit, which is considered to be decisive in various methods, has partial information, insufficient to decide on the need to repair the electric machine, the actual state of the stator winding or predict the time of trouble-free operation.

To increase the reliability of diagnosis and differentiation of the degree of inter-turn circuits in the stator requires a systematic approach based on the analysis of factors using electrical, magnetic, thermal and vibration parameters with the mandatory implementation of decision theory.

\section{Література}

1. Петухов В.С., Соколов В.А. Диагностика состояния электродвигателей. Метод спектрального анализа потребляемого тока. Новости электротехники. Санкт-Петербург : ЗАО Новости Электротехники, 2005. № 1.63 с.

2. Чернышев В.А., Сафроненков Ю.Ф., Гордиловский А.А., Чернов В.А. Современные подходы к оценке состояния изоляции электрических машин высокого напряжения. Электротехника. Москва : ЗАО Знак, 2008. № 4.92 с.

3. Сидельников Л.Г., Афанасьев Д.О. Обзор методов контроля технического состояния асинхронных двигателей в процессе эксплуатации. Вестник Пермского национального исследовательского политехнического университета. Геология. Нефтегазовое и горное дело. 2013. № 7. С. 127-137.

4. Хомутов С.О. Комплекс мероприятий по повышению надежности электрических двигателей в сельском хозяйстве на основе достоверных методов диагностики и эффективных технологий восстановления изоляции. Ползуновский вестник. 2010. № 4/2. С. 70-76.

5. Губаревич О.В., Голубєва С.М. Аналіз методів діагностики технічного стану ізоляції асинхронних двигунів. Наукові праці Донецького національного технічного університету. Електротехніка і енергетика. 2019. №1(21), С. 55-63.

6. Воробьев Н.П., Воробьева С.Н., Суханкин Г.В., Герцен Н.Т. Методы и приборы диагностирования изоляции асинхронных двигателей. Ползуновский вестник. 2011. № 2/2. С. 261-269.

7. Худий С.Г., Пельтек I.I. Сучасні методи діагностики стану ізоляції електричних машин. Вестник НТУ «ХПИ»: Проблеми автоматизованого електроприводу. Теорія $і$ практика. 2010. № 28 C. 549 550. ISSN 2079-8024.

8. Титко А.И., Андриенко В.М., Худяков А. В., Гуторова М.С. Новые методы диагностики асинхронных двигателей. Праці Інституту електродинаміки Національної академії наук України. 2014. Вип. 37. С. 58-61.

9. Диагностика и прогнозирование состояния асинхронных двигателей на основе использования параметров их внешнего электромагнитного поля / А.Ю. Алексеенко, О.В. Бродский, В.Н. Веденеев, В.Г. Тонких, С.О. Хомутов. Вестник Алтай. гос. техн. ун-та им. И.И. Ползунова. 2006. № 2. С. 79-83. 
10. Губаревич О.В., Гулак С.О., Голубєва С.М. Комплексний підхід до діагностування асинхронних електродвигунів водного транспорту. Новітні технології. 2019. Вип. 2(9). С.48-61.

11. Руссов В.А. Диагностика дефектов вращающегося оборудования по вибрационным сигналам. Пермь : 2012. 252 с.

12. Губаревич О.В., Козынко А.С. Природа вибрации и современные методы вибродиагностики электрических машин. Вісник Східноукраӥнського наи. ун-ту ім. В. Даля. 2017, №3 (233). С.53-58.

13. Гуторова М.С. Електромагнітний спосіб діагностики виткових замикань статорної обмотки АД. Праці Ін-ту електродинаміки НАН України. 2008. № 20. С. 42.

14. Вовк О.Ю., Квітка С.О., Яковлєв В.Ф. Аналітичне порівняння методів визначення усталеного перевищення температури обмоток статора асинхронного електродвигуна. Вісник Сумського національного аграрного університету. Механізація та автоматизація виробничих проиесів. 2011. № 8(23). C.114-116.

15. Грабко В.В., Грабко В.В. Математическая модель для диагностирования состояния изоляции работающей мощной электрической машины по ее тепловому портрету. Наукові праці ВНТУ. 2008. № $1.178 \mathrm{c}$.

16. Петухов В. Диагностика электродвигателей. Спектральный анализ модулей векторов Парка тока и напряжения. Новости электротехники. 2008. № 1 (50). С. 33-37.

17. Thomson W.T. A Review of On-Line Condition Monitoring Techniques for Three-Phase Squirrel-Cage Induction Motors - Past, Present and Future. Keynote address at IEEE Symposium on Diagnostics for Electrical Machines, Power Electronics and Drives, Gijon, Spain, Sept. 1999, pp 3-18.

18. Pustovetov M.Yu. A mathematical model of the three-phase induction motor in three-phase stator reference frame describing electromagnetic and electromechanical processes. IEEE Conference 2016 Dynamics of Systems, Mechanisms and Machines (Omsk, 2016).

19. Gyftakis K.N., Cardoso A. J. M. A new space vector approach to detect stator faults in induction motors. 2017 IEEE Workshop on Electrical Machines Design, Control and Diagnosis (WEMDCD). IEEE. 2017. P. 232-237.

20. Goolak S., Gubarevych O., Yermolenko E, Slobodyanyuk M, Gorobchenko O. Mathematical modeling of an induction motor for vehicles. Eastern-European Journal of Enterprise Technologies. 2020. 2/2 (104). 25-34. DOI: https://doi.org/10.15587/1729-4061.2020.199559.

21. Pustovetov M.Yu. Approach to Computer Implementation of Mathematical Model of 3-Phase Induction Motor. IOP Conf. Series: Materials Science and Engineering 327 (2018) 022085. DOI:10.1088/1757899X/327/2/022085.

22. Goolak, S.: Methodological recommendations for the application of the model of physical processes in three-phase asynchronous motor. Collection of scientific works of the State economic-technological university of transport. Transport Systems and Technologies. 2018. 1(32). P. 4-13.

23. Abdullah, Afrah Thamer, Amer Mejbel Ali. Estimation of Stator Winding Temperature of a ThreePhase Induction Motor. IRAQI JOURNAL OF COMPUTERS, COMMUNICATION AND CONTROL \& SYSTEMS ENGINEERING. 2019. 19, 2. P. 9-17.

24. Mao, Xiaoming, and Junxian Chen. A Fast Method to Compute the Dynamic Response of Induction Motor Loads Considering the Negative-Sequence Components in Stability Studies. Energies. 2019. 12. P. 1802-1818.

\section{References}

1. Petukhov, V.S., \& Sokolov, V.A. (2005). Diagnostics of the condition of electric motors. Method of spectral analysis of current consumption. Novosti elektrotekhniki, Sankt-Peterburg: ZAO Novosti Elektrotekhniki, 1.

2. Chernyshev, V.A., Safronenkov, YU.F., Gordilovskiy, A.A., \& Chernov, V.A. (2008), Modern approaches to assessing the insulation state of high-voltage electric machines. Elektrotekhnika, Moscow: ZAO Znak, 4.

3. Sidel'nikov, L.G., \& Afanas'yev, D.O. (2013). A review of methods for monitoring the technical condition of induction motors during operation. Vestnik Permskogo natsional'nogo issledovatel'skogo politekhnicheskogo universiteta. Geologiya. Neftegazovoye i gornoye delo, 7, 127-137.

4. Khomutov, S.O. (2010). A set of measures to improve the reliability of electric motors in agriculture based on reliable diagnostic methods and effective insulation recovery technologies. Polzunovskiy vestnik. 4/2, 70-76. 
5. Gubarevych, O.V. \& Golubyeva, S.M. (2019). Analysis of methods for diagnosing a technical camp of asynchronous motors. Science and Technology of Donetsk National Technical University. Electrotechnics and energy, 1(21), 55-63.

6. Vorob'yev, N.P., Vorob'yeva, S.N., Sukhankin, G.V., \& Gertsen, N.T. (2011), Methods and instruments for diagnosing insulation of asynchronous motors. Polzunovskiy vestnik, 2, 2, 261-269.

7. Khudyy, YE.H., \& Pel'tek, I.I. (2010). Modern methods of diagnostics of the state of insulation of electric machines. Problemy avtomatyzovanoho elektropryvodu. Teoriya i praktyka, 28, 549-550.

8. Titko, A.I., Andriyenko, V.M,. Khudyakov, A.V, \& Gutorova, M.S. (2014). New diagnostic methods for induction motors. Pratsi Instytutu elektrodynamiky Natsional'noyi akademiyi nauk Ukrayiny, 37, 58-61.

9. Alekseyenko, A.YU., Brodskiy, O.V., Vedeneyev, V.N., Tonkikh, V.G., \& Khomutov, S.O. (2006). Diagnosis and prediction of the status of induction motors based on the use of the parameters of their external electromagnetic field. Vestnik Altay. gos. tekhn. un-ta im. I.I. Polzunova, 2, 79-83.

10. Gubarevych, O.V., Goolak, S.O. \& Golubyeva, S.M. (2019). A comprehensive approach to diagnosing asynchronous electric motors of water transport. New technology, 2 (9), 48-61.

11. Russov, V.A. (2012). Diagnostika defektov vrashchayushchegosya oborudovaniya po vibratsionnym signalam. Perm: Russia.

12. Gubarevych, O.V. \& Kozynko, A.S. (2017). The nature of vibration and modern methods of vibrodiagnosis of electric machines. Visnyk Skhidnoukrayins'koho nats. un-tu im. V. Dalya, 3, 233, 53-58.

13. Gutorova, M.S. (2008). The electromagnetic method of diagnostics of winding of a circuit of a stator windings AM. Proceedings of the Institute of Electrodynamics of NAS of Ukraine, 20.

14. Vovk, O. YU., Kvitka, S.O., \& Yakovlyev, V.F. (2011). Analytical comparison of methods for determining the stationary excess of the stator windings of an induction motor. Visnyk Sumskoho natsionalnoho ahrarnoho universytetu. "Mechanization and automation of production processes", 8 (23), 114-116.

15. Grabko, V.V., \& Grabko, V.V. (2008). A mathematical model for diagnosing the insulation state of a working powerful electric machine according to its thermal portrait. Naukoví pratsí VNTU, 1.

16. Petukhov, V.S. (2008). Diagnostics of electric motors. Spectral analysis of modules of vectors of the Park of current and voltage. Part 1, Novosti elektrotekhniki, 1 (50), 33-37.

17. Thomson, W.T. (1999). A Review of On-Line Condition Monitoring Techniques for Three-Phase Squirrel-Cage Induction Motors - Past, Present and Future. Keynote address at IEEE Symposium on Diagnostics for Electrical Machines, Power Electronics and Drives, Gijon, Spain, Sept. 1999, pp. 3-18.

18. Pustovetov, M.Yu. (2016). A mathematical model of the three-phase induction motor in three-phase stator reference frame describing electromagnetic and electromechanical processes. IEEE Conference 2016 Dynamics of Systems, Mechanisms and Machines, Omsk, Russia.

19. Gyftakis, K.N., \& Cardoso, A.J.M. (2017). A new space vector approach to detect stator faults in induction motors. IEEE Workshop on Electrical Machines Design, Control and Diagnosis (WEMDCD). IEEE, pp. 232-237.

20. Goolak, S., Gubarevych, O., Yermolenko, E., Slobodyanyuk, M., \& Gorobchenko, O. (2020). Mathematical modeling of an induction motor for vehicles. Eastern-European Journal of Enterprise Technologies, 2/2 (104). 25-34. DOI: https://doi.org/10.15587/1729-4061.2020.199559.

21. Pustovetov, M.Yu. (2018). Approach to Computer Implementation of Mathematical Model of 3-Phase Induction Motor. IOP Conf. Series: Materials Science and Engineering, 327, 022085. DOI: 10.1088/1757-899X/327/2/022085.

22. Goolak, S. (2018). Methodological recommendations for the application of the model of physical processes in three-phase asynchronous motor. Collection of scientific works of the State economictechnological university of transport. Series: Transport Systems and Technologies, 1 (32), 4-13.

23. Abdullah Afrah Thamer, \& Amer Mejbel Ali. (2019). Estimation of Stator Winding Temperature of a Three-Phase Induction Motor. IRAQI JOURNAL OF COMPUTERS, COMMUNICATION AND CONTROL \& SYSTEMS ENGINEERING, 19, 2, 9-17.

24. Mao Xiaoming, \& Junxian Chen (2019). A Fast Method to Compute the Dynamic Response of Induction Motor Loads Considering the Negative-Sequence Components in Stability Studies. Energies, 12, 1802-1818.

Губаревич Олег Володимирович; Gubarevych Oleg, ORCID: https://orcid.org/0000-0001-7864-0831

Гулак Сергій Олександрович; Goolak Sergey, ORCID: https://orcid.org/0000-0002-2294-5676 